Економічні науки: збірник наукових праџь Луцького національного технічного університету. Серія “Регіональна економіка". Випуск 18 (71). Редкол.: відп. ред. д.е.н., професор Л.Л. Ковальська. Луцьк: ІВВ Луцького НТУ, 2021. 278 с.

УДК 656.076:338.47

Василик Н.М., к.е.н., доцент,

Корецька Н.І., к.е.Н., доцент,

Луцький національний технічний університет

\title{
УПРАВЛІННЯ ЯКІСТЮ НАДАННЯ ТРАНСПОРТНИХ ПОСЛУГ СПЕЦТЕХНІКОЮ НА ОСНОВІ КРЕАТИВНИХ ПІДХОДІВ
}

Стаття присвячена розгляду ключових аспектів управління якістю надання транспортних послуг спецтехнікою. Розглянуто важливість управління якістю надання транспортних послуг із використанням клієнтоорієнтованого підходу. Проведено оцінку рівня якості надання транспортних послуг спецтехнікою та ефективності управління на конкретному підприємстві Волинської області. Запропоновано підприємству шляхи удосконалення управління якістю надання транспортних послуг спецтехнікою із застосуванням креативних підходів.

Ключові слова: управління якістю, оцінка рівня якості надання транспортних послуг, управління якістю надання транспортних послуг.

\section{Vasilik N., Koretska N. \\ QUALITY MANAGEMENT OF PROVISION OF TRANSPORT SERVICES BY SPECIAL EQUIPMENT ON THE BASIS OF CREATIVE APPROACHES}

The article is devoted to the consideration of key aspects of quality management of transport services by special equipment. The importance of quality management of transport services using a customer-oriented approach is considered.

Effective quality management of transport services allows companies in this area to best meet the needs of consumers (customers) and increase competitiveness and profitability.

Quality management of transport services by special equipment is a set of approaches, methods, methods of effective provision of transport services by special equipment, compliance with requirements, terms, norms and standards, in order to meet customer needs.

The object of the study was one of the leading enterprises of the Volyn region LLC "SPETS TECH ZAKHID", the main activities of which are the provision of special equipment, freight, rental of special equipment, sale of bulk construction materials (sand, gravel, cement).

The article presents an assessment of the level of quality of transport services by special equipment from the point of view of the enterprise and from the point of view of customers. It was determined that LLC "SPEC TECH ZAKHID" 
Економічні науки: збірник наукових праџь Луцького національного технічного університету. Серія "Регіональна економіка". Випуск 18 (71). Редкол.: відп. ред. д.е.н., професор Л.Л. Ковальська. Луиьк: ІВВ Луцького НТУ, 2021. 278 с.

overestimates the level of quality of its services to customers. The overall adequacy ratio of quality assessment was 0.91 . But in general, both customers and the company itself assessed the level of quality of service at a high level.

In order to develop an effective mechanism to improve the quality of transport services, the company needs to adequately assess the effectiveness of quality management of transport services. To this end, in the course of the study, we diagnosed the existing quality management system for the provision of transport services at LLC “SPETS TECH ZAKHID”.

It was found that the company has a number of positive approaches to quality management of transport services with special equipment, but there are some reserves for improvement and refinement.

Based on the conducted research and analysis for LLC "SPETS TECH ZAKHID", it is necessary to implement a number of creative measures to improve the quality management of transport services by special equipment, in particular: to introduce the position of customer relations and quality manager; develop and implement a quality management system (QMS) and obtain ISO certification, use such innovative creative methods of forecasting and improving quality and management as: benchmarking, controlling, budgeting, $\mathrm{ABC}$ analysis, Paretto principle, "Just in time" approach, outsourcing, insourcing and others; systematically conduct internal and external quantitative and qualitative (expert) assessment of the quality of transport services with mandatory customer surveys, improve and supplement information about the company and its services on the site, disseminate information in the media, strengthen the positive image of the company; to improve methods and means of feedback with customers by introducing the service on the site "We will call you back", supplementing the site of the company with the section "Customer opinion"; develop an effective system of work motivation, which would encourage employees to perform their work well and be polite to customers; to improve organizational culture.

Key words: quality management, assessment of the level of quality of transport services, quality management of transport services.

\section{Василик Н.М., Корецкая Н.И. УПРАВЛЕНИЕ КАЧЕСТВОМ ПРЕДОСТАВЛЕНИЯ ТРАНСПОРТНЫХ УСЛУГ СПЕЦТЕХНИКОЙ НА ОСНОВЕ КРЕАТИВНЫХ ПОДХОДОВ}

Статья посвящена рассмотрению ключевых аспектов управления качеством предоставления транспортных услуг спецтехникой. Рассмотрена важность управления качеством предоставления транспортных услуг с использованием клиентоориентированного подхода. Проведена оценка уровня качества предоставления транспортных услуг спецтехникой и эффективности управления на конкретном предприятии Волынской области. Предложены 
Економічні науки: збірник наукових прачь Луиького національного технічного університету. Серія "Регіональна економіка". Випуск 18 (71). Редкол.: відп. ред. д.е.н., професор Л.Л. Ковальська. Луиьк: ІВВ Луцького НТУ, 2021. 278 с.

предприятию пути усовершенствования управления качеством предоставления транспортных услуг спецтехникой с применением креативных подходов.

Ключевые слова: управление качеством, оценка уровня качества предоставления транспортных услуг, управление качеством предоставления транспортных услуг.

\section{Постановка проблеми у загальному вигляді та її зв'язок 3} важливими науковими та практичними завданнями. Транспортні послуги спецтехнікою $є$ однім із видів транспортрно-еспедиційних послуг і відіграють важливу роль у сфері будівництва та благоустрою як для звичайних домогосподарств так і для підприємств, установ різних форм власності і видів діяльності, територіальних громад, органів влади, тим самим забезпечують соціально-економічний розвиток регіонів та держави в цій сфері. Зі зміною економічних відносин та інформатизації суспільства, змінилися і вимоги до надання послуг спецтехнікою.

Саме клієнт (споживач) транспортних послуг тепер відіграє провідну і визначальну роль та диктує вимоги та напрями транспортного обслуговування. 3 огляду на це, щоб отримати конкурентні перевага та прихильність клієнтів, підприємствам в даній сфері необхідно систематично проводити оцінку якості надання транспортних послуг, удосконалювати систему управління якістю із застосуванням нових креативних підходів.

Аналіз останніх досліджень, у яких започатковано вирішення проблеми. Висвітленню сутності, вимог, методів оцінки рівня якості надання та управління транспортними послугами займалась ціла низка науковців, серед яким варто виділити таких: В. Біліченко, В. Бондаренко, В. Вінокуров, Н. Гринів, Я. Зав'ялова, К. Зорін, В. Ільченко, О. Криворучко, Г. Кучерук, Д. Мажуга, І. Майорова, Д. Маслов, А. Матвєєва, М. Матвієнко, О. Нечепуренко, С. Петровська, Ю. Пічугіна, Г. Подвальна, А. Пятих, Б. Райзберг, І. Савельєва, А. Свершок, С. Свиридко, В. Стаднік, Л. Шокіна, В. Щербина та інші.

Основні постулати розуміння, впровадження та розвитку системи управління якістю були сформовані технічним 
Економічні науки: збірник наукових праџь Луцького національного технічного університету. Серія "Регіональна економіка". Випуск 18 (71). Редкол.: відп. ред. д.е.н., професор Л.Л. Ковальська. Луцьк: ІВВ Луиького НТУ, 2021. 278 с.

комітетом ISO/TK 176 Міжнародної організації iз стандартизації, яким розроблено комплекс стандартів 3 якості ISO 9000, стандарт для аудиту систем якості та/або системи екологічного менеджменту ISO 19011. Загалом дані стандарти дозволяють ефективно впроваджувати систему менеджменту якості на підприємствах та проходити сертифікацію. Для сфери транспортного обслуговування діє ISO/TS 16949:2002 Система менеджменту якості - Окремі вимоги щодо застосування ISO 9001:2000 в автомобільній промисловості і організацій, які надають відповідні послуги.

Попова О.Ю. та Скибенко Г.Г. у своїх дослідженнях [1], відмічають, що більшість вітчизняних підприємств все ще не здатні або не вважають необхідним розвивати управління якістю в контексті розвитку підприємства, проте «системи управляння якістю слід вважати безумовно необхідним плацдармом для вітчизняних промислових підприємств, який має збільшувати рівень відповідності сучасним інноваційним технологіям» [1].

Г. Кучерук [2], систематизував та виділив економічних методів управління якістю продукції (послуги), групуючи їх на класичні та інноваційні методи (рис. 1).

В свою чергу, низка вітчизняних науковців, зокрема, М. Бутко, Д. Зінкевич, О. Кузьмін, С.В. Князь, І.В. Литвин, Н. Мала, О. Продіус, І. Свидрук, Н. Савіцька та інші, в своїх публікаціях наголошують на важливості i трендовості застосування креативних підходів в управлінні.

Ці аспекти є важливими і для підприємств у сфері наданні транспортних послуг спецтехнікою. Але детальний огляд наукових джерел показав, що конкретні рекомендації для даних підприємств, щодо управління якістю надання транспортних послуг спецтехнікою, не були розглянуті в працях науковців, що і зумовило необхідність розкриття цієї проблеми в даній статті.

Цілі статті. Виділення основних напрямів удосконалення управління якістю надання транспортних послуг спецтехнікою на підприємстві на основі креативних підходів. 
Економічні науки: збірник наукових праџь Луцького національного технічного університету. Серія "Регіональна економіка". Випуск 18 (71). Редкол.: відп. ред. д.е.н., професор Л.Л. Ковальська. Луцьк: ІВВ Луцького НТУ, 2021. 278 с.

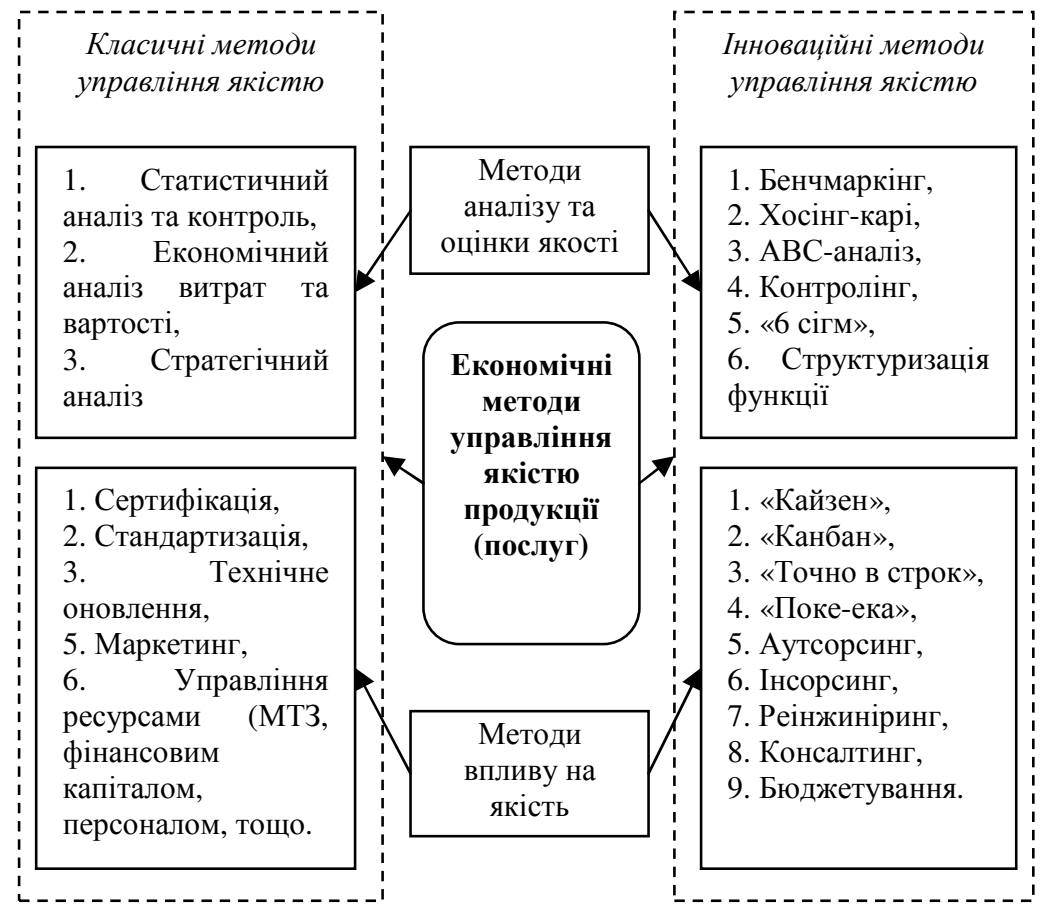

Рис. 1. Класифікація економічних методів управління якістю продукції (послуги) [2]

\section{Виклад основного матеріалу дослідження 3 повним обгрунтуванням отриманих наукових результатів.} Забезпечення належного рівня якості надання транспортних послуг спецтехнікою та в цілому ефективності діяльності транспортно-логістичного підприємства можливе завдяки впровадженню ефективної системи управління якістю. Це дозволить підприємству в повній мірі задовольняти запити клієнтів та покращувати своє економічне та ринкове становище.

Система управління якістю надання транспортних послуг спецтехнікою повинна враховувати вимоги та запити споживачів, бути інноваційною, результативною, орієнтуватись на TQM (Total Quality Management) та в підсумку бути 
Економічні науки: збірник наукових праџь Луцького національного технічного університету. Серія "Регіональна економіка". Випуск 18 (71). Редкол.: відп. ред. д.е.н., професор Л.Л. Ковальська. Луиьк: ІВВ Луиького НТУ, 2021. 278 с.

спрямованою на сертифікацію підприємства відповідно до стандартів якості ISO 9000.

Управління якістю надання транспортних послуг спецтехнікою - це сукупність підходів, способів, методів ефективного надання транспортних послуг спецтехнікою, дотримання вимог, термінів, нормативів та стандартів, 3 метою задоволення потреб клієнтів.

Під час формування системи управління якістю надання транспортних послуг на підприємстві, необхідно враховувати, що низка зовнішніх і внутрішніх факторів можуть впливати на даний процес. На думку вчених [3], в діяльності транспортних підприємств, можна виділити низку внутрішніх проблемних сторін, що впливають на якість, це: «невелика чисельність персоналу; недостатня гнучкість і пристосованість управління до нових умов господарювання; низька управлінська компетенція керівників та фахівців (в результаті неналежним чином виконуються такі функції, як маркетинг, управління логістичними операціями, організація управління, управління персоналом, менеджмент якості продукції, послуг, стратегічне планування i управління розвитком компаніі, управління фінансовими потоками, аналіз фінансових витрат, тощо); недостатнє забезпечення управління» [3].

Разом 3 тим, якщо на підприємстві буде забезпечено формування креативного середовища, розкриття та максимальне залучення креативного потенціалу працівників, використання креативних методів генерування ідей та прийняття управлінських рішень і вцілому підтримка та мотивування креативних підходів, то це дозволить ефективно вести конкурентну боротьбу і отримувати лідируючі позиції на ринку.

В свою чергу, щоб зрозуміти наскільки ефективно здійснюється управління якістю надання транспортних послуг спецтехнікою на підприємстві, необхідно обов'язково здійснювати комплексну систематичну оцінку рівня якості надання послуг та управління. Така оцінка дозволить вчасно виявити недоліки в обслуговуванні клієнтів та вузькі місця в діяльності підприємства. 
Економічні науки: збірник наукових праџь Луцького національного технічного університету. Серія “Регіональна економіка". Випуск 18 (71). Редкол.: відп. ред. д.е.н., професор Л.Л. Ковальська. Луиьк: ІВВ Луиького НТУ, 2021. 278 с.

Науковці мало уваги приділили розробці методик оцінки саме рівня управління якістю надання транспортних послуг. 3 огляду на це, ми спробували на конкретному підприємстві, яке надає послуги спецтехнікою, розробити та апробувати нові креативні підходи оцінки рівня якості надання транспортних послуг спецтехнікою на основі зіставлення оцінок клієнтів та самого підприємства та методику оцінку ефективності управління якістю надання транспортних послуг спецтехнікою шляхом побудови профілю.

Для аналізу ми обрали одне із провідних транспортних підприємств Волинської області ТОВ «СПЕЦ ТЕХ ЗАХІД», яке більше десятка років функціонує на ринку. Воно спеціалізується на вантажних перевезеннях, наданні послуг спецтехнікою та продажу сипучих будматеріалів (пісок, щебінь, цемент) [4]. На сьогоднішній день для виконання робіт підприємство «має сучасний парк авто та спецтехніки різного призначення, а саме: 30 одиниць - самоскиди з напівпричепами Renaultб Volvo, DAF, MAN iз загрузкою для перевезення будівельних матеріалів; Бульдозер Liebherr 17 т; Екскаватор VOLVO 1,5 куб. (гусеничний); Фронтальний навантажувач 2,5 куб.; Телескопічний навантажувач 2 куб. Впроваджено систему транспортної навігації (GPS), що дає можливість контролювати переміщення та безпеку вантажів. Має досвід у будівництві доріг та співпраці з провідними компаніями України» [4].

Основними конкурентами даного підприємства в області $є$ ТОВ «Джин Спецтех», ТОВ «Надра», ТОВ «Ремплюсбуд», TOB «LincTrans» та ряд приватних підприємців.

Значною перевагою, є те, що ТОВ «СПЕЦ ТЕХ ЗАХІД» має власний сайт (http://spectex.pp.ua/) де чітко i зрозуміло представлена інформація про саме підприємство та товари i послуги (з зазначенням вартості послуг), які пропонує клієнтам.

Отже, проведемо оцінку рівня якості надання транспортних послуг ТОВ «СПЕЦ ТЕХ ЗАХІД» експертним шляхом за 10-ти бальною шкалою. При цьому враховуючи основний принцип - клієнтоорієнтованість, оцінка параметрів була проведена окремо клієнтами та окремо підприємством. 
Економічні науки: збірник наукових праџь Луцького національного технічного університету. Серія “Регіональна економіка". Випуск 18 (71). Редкол.: відп. ред. д.е.н., професор Л.Л. Ковальська. Луцьк: ІВВ Луцького НТУ, 2021. 278 с.

Наочне співставлення оцінки якості надання транспортних послуг підприємством та клієнтами по визначених показниках подане на рисунку 2.

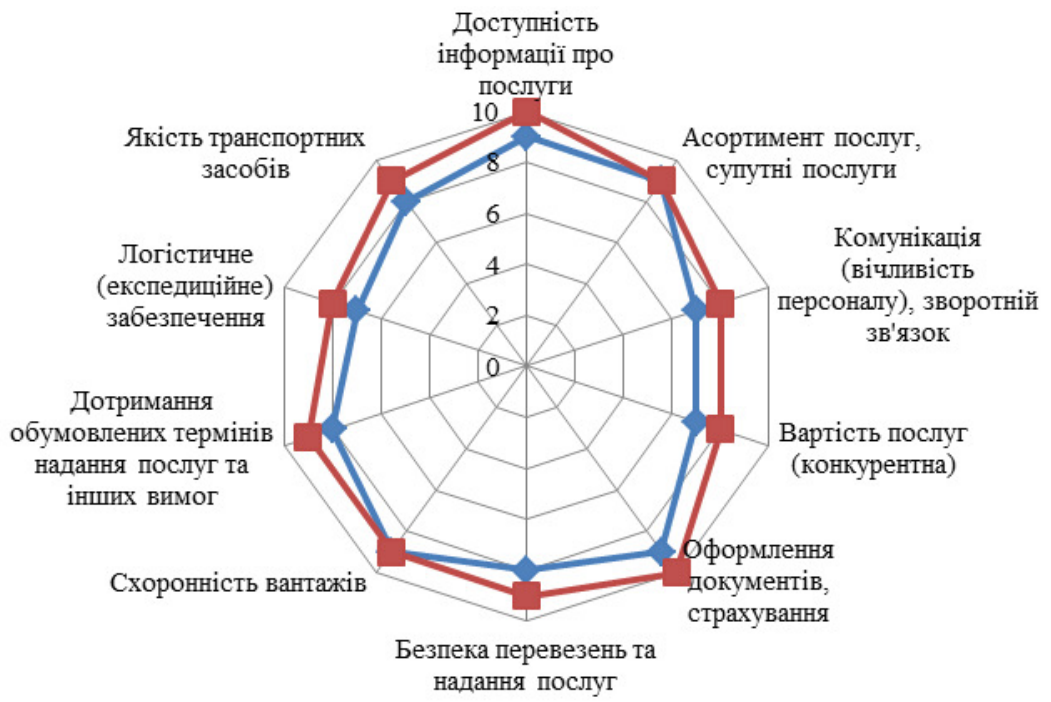

$\longrightarrow$ Середня оцінка клієнтів (мах 10 б) - - Середня оцінка компаніі (мах 106 )

Рис. 2. Порівняння результатів оцінки якості надання транспортних послуг клієнтами та ТОВ «СПЕЦ ТЕХ ЗАХІД» Примітка: сформовано авторами

Загалом, загальна експертна самооцінка підприємства по показниках склала 89 балів (при мах 100), а оцінка клієнтів рівня якості надання транспортних послуг підприємством склала 81 балів. Тобто видно, що ТОВ «СПЕЦ ТЕХ ЗАХІД» переоцінює рівень якості надання своїх послуг клієнтам.

Загальний коефіцієнт адекватності оцінки якості склав 0,91. При цьому, найбільш об'єктивно було оцінено рівень якості по таких параметрах, як схоронність вантажів, асортимент послуг.

Далі, в процесі аналізу, також було розраховано комплексний рівень якості надання послуг підприємством знову iз позиції клієнтів та самого підприємства, і відповідно ці 
Економічні науки: збірник наукових праџь Луцького національного технічного університету. Серія "Регіональна економіка". Випуск 18 (71). Редкол.: відп. ред. д.е.н., професор Л.Л. Ковальська. Луцьк: ІВВ Луцького НТУ, 2021. 278 с.

показники склали 8,06 та 8,86. Використовуючи рекомендовану оціночну шкалу: 0-3,3 - низький рівень; 3,4-6,6 - середній рівень; 6,7-10 високий рівень якості надання транспортних послуг, то ТОВ «СПЕЦ ТЕХ ЗАХІД» на високому рівні надає транспортні послуги, як з точки зору самооцінки так із позиції клієнтів, але є ще резерви для удосконалення і розвитку.

На наступному етапі дослідження, пропонуємо провести оцінку ефективності управління якістю надання транспортних послуг ТОВ «СПЕЦ ТЕХ ЗАХІД» шляхом виділення і оцінки експертним шляхом, на нашу думку, найбільш важливих параметрів управління якістю та представлення оцінки у вигляді профілю із бальною оцінкою від 1 до 5 та коротким описом реальних досягнень підприємства (табл. 1).

Таблиця 1

Профіль ефективності управління якістю надання транспортних послуг ТОВ «СПЕЦ ТЕХ ЗАХІД»

\begin{tabular}{|c|c|c|c|c|c|c|}
\hline \multirow{2}{*}{ Параметри } & \multicolumn{5}{|c|}{ Бали } & \multirow{2}{*}{ Коротка характеристика } \\
\hline & 1 & 2 & 3 & 4 & 5 & \\
\hline 1 & 2 & 3 & 4 & 5 & 6 & 7 \\
\hline Асортимент послуг & & & & $*$ & & Найбільших в області \\
\hline $\begin{array}{l}\text { Надійність зв’язків } \\
\text { постачальниками }\end{array}$ & & & & & $*$ & $\begin{array}{l}\text { Налагоджені } \\
\text { постачальниками } \\
\text { довгострокові зв'язки }\end{array}$ \\
\hline Логістичне обслуговування & & & & $*$ & & На підприємстві є логіст \\
\hline Час виконання заявки & & & & $*$ & & $\begin{array}{l}\text { Швидка обробка заявки, } \\
\text { виконання }\end{array}$ \\
\hline $\begin{array}{l}\text { Спостереження, } \text { контроль } \\
\text { за ходом виконання заявки }\end{array}$ & & & & $*$ & & $\begin{array}{l}\text { Підтримка } \\
\text { зв'язку з клієнтами, GPS }\end{array}$ \\
\hline $\begin{array}{ll}\text { Оформлення } \\
\text { документації }\end{array}$ & & & & & $*$ & $\begin{array}{l}\text { Супровід заявок необхідною } \\
\text { документацією }\end{array}$ \\
\hline Репутація (імідж) компанії & & & & & $*$ & $\begin{array}{l}\text { Відмінна репутація в області } \\
\text { та Україні }\end{array}$ \\
\hline $\begin{array}{l}\text { Дотримання встановлених } \\
\text { вимог та правил надання } \\
\text { послуг }\end{array}$ & & & & $*$ & & \begin{tabular}{ll} 
Дотримання & \multicolumn{2}{c}{ стандартів } \\
ДСТУ та & корпоративних \\
вимог та правил, умов \\
договорів
\end{tabular} \\
\hline Сертифікат ISO & $*$ & & & & & Відсутність сертифікації \\
\hline Наявність клієнтської бази & & & $*$ & & & Клієнтська база наповнюється \\
\hline $\begin{array}{l}\text { Частка клієнтів, які повторно } \\
\text { звернулись за послугами }\end{array}$ & & & * & & & Орієнтовно складає $55 \%$ \\
\hline $\begin{array}{l}\text { Проведення дослідження } \\
\text { потреб споживачів }\end{array}$ & & & $*$ & & & $\begin{array}{l}\text { Несистематично } \\
\text { проводиться дослідження } \\
\text { потреб споживачів }\end{array}$ \\
\hline
\end{tabular}


Економічні науки: збірник наукових праџь Луцького національного технічного університету. Серія "Регіональна економіка". Випуск 18 (71). Редкол.: відп. ред. д.е.н., професор Л.Л. Ковальська. Луцьк: ІВВ Луцького НТУ, 2021. 278 с.

Продовження табл. 1

\begin{tabular}{|c|c|c|c|c|c|c|}
\hline 1 & 2 & 3 & 4 & 5 & 6 & 7 \\
\hline $\begin{array}{lr}\text { Проведення } & \text { оцінки } \\
\text { задоволеності } \\
\text { послугами }\end{array}$ & & & $*$ & & & $\begin{array}{lr}\text { Вибірково } & \text { проводиться } \\
\text { оцінка } & \text { задоволеності } \\
\text { клієнтів } & \\
\end{array}$ \\
\hline Частка задоволених клієнтів & & & & $*$ & & Орієнтовно складає $85 \%$ \\
\hline $\begin{array}{l}\text { Рівень інформаційного } \\
\text { забезпечення }\end{array}$ & & & & $*$ & & \begin{tabular}{lr} 
Належне & \multicolumn{2}{c}{ програмне } \\
забезпечення, \\
підприємства
\end{tabular} \\
\hline $\begin{array}{l}\text { Комунікабельний, ввічни- } \\
\text { вий персонал, належний } \\
\text { зворотній } \\
\text { клієнтами }\end{array}$ & & & $*$ & & & $\begin{array}{l}\text { 3воротній зв'язок реалізується } \\
\text { телефоном, емейлом, через } \\
\text { сайт, очні } \\
\text { Переважно бесіди, ЗМІ. } \\
\text { комунікабельний персонал }\end{array}$ \\
\hline $\begin{array}{l}\text { Планування та прогно- } \\
\text { зування заходів із підви- } \\
\text { щення якості управління }\end{array}$ & & & $*$ & & & $\begin{array}{l}\text { Проводиться } \\
\text { несистематично, вибірково }\end{array}$ \\
\hline \begin{tabular}{lr} 
Наявність & підрозділу чи \\
посадової & особи, який \\
координує & \multicolumn{2}{c}{ процеси } \\
управління якістю
\end{tabular} & & & & $*$ & & $\begin{array}{l}\text { Немає окремого підрозділу. } \\
\text { Функції виконує директор, } \\
\text { логіст, головний механік, } \\
\text { менеджер зі збуту }\end{array}$ \\
\hline $\begin{array}{l}\text { Придбання нових } \\
\text { транспортних засобів і } \\
\text { підтримка належного тех- } \\
\text { нічного стану в наявних }\end{array}$ & & & & $*$ & & $\begin{array}{lr}\text { Щорічне } & \text { оновлення } \\
\text { автопарку. } & \text { Дотримання } \\
\text { належного технічного стану } \\
\text { автомобілів }\end{array}$ \\
\hline $\begin{array}{l}\text { Здійснення систематичної } \\
\text { оцінки рівня якості }\end{array}$ & & & $*$ & & & \begin{tabular}{ll} 
Відсутність & \multicolumn{2}{c}{ комплексної } \\
методики & оцінки, лише \\
вибіркова & \\
\end{tabular} \\
\hline $\begin{array}{l}\text { Стимулювання персоналу } \\
\text { за якісне надання послуг }\end{array}$ & & & $*$ & & & $\begin{array}{l}\text { Система } \quad \text { стимулювання } \\
\text { потребує вдосконалення }\end{array}$ \\
\hline
\end{tabular}

Примітка: сформовано авторами

Таким чином можна відмітити, що ТОВ «СПЕЦ ТЕХ ЗАХІД» має низку позитивних підходів до управління якістю надання транспортних послуг спецтехнікою, але прослідковуються певні резерви для покращення і вдосконалення.

Отже, на основі проведених досліджень і аналізу, на нашу думку, для ТОВ «СПЕЦ ТЕХ ЗАХІД» варто реалізувати низку нових креативних заходів із вдосконалення управління якістю надання транспортних послуг спецтехнікою, зокрема:

- ввести посаду менеджера 3 підтримки зв'язків 3 клієнтами та якості, а також ще одну посаду логіста;

- розробити та впровадити систему менеджменту якості (СМЯ) та отримати сертифікат, про відповідність якості надання 
Економічні науки: збірник наукових прачь Луиького національного технічного університету. Серія “Регіональна економіка". Випуск 18 (71). Редкол.: відп. ред. д.е.н., професор Л.Л. Ковальська. Луиьк: ІВВ Луцького НТУ, 2021. 278 с.

транспортних послуг підприємством стандартам ISO;

- використовувати такі інноваційні методи удосконалення якості та управління: бюджетування, АВС-аналіз, бенчмаркінг, принцип Паретто, підхід «Точно в строк», аутсорминг, інсорсинг, контролінг та інші;

- систематично проводити, за методиками, які були наведені вище в статті, кількісну та якісну (експертну) оцінку якості надання транспортних послуг та оцінку ефективності управління із обов' язковим опитуванням клієнтів,

- використовувати паблік-рілейшинз у діяльності;

- посилити засоби та методи зворотного зв'язку 3 клієнтами, наприклад, шляхом доповнення сайту підприємства розділом «Думка клієнтів» (розмістити опитувальник клієнтів) та введення послуги на сайті «Ми вам передзвонимо», також варто розмісти стрічки для відгуків і пропозицій кліснтів;

- систематично досліджувати та прогнозувати потреби кліснтів, оцінювати ризики і загрози із зовнішнього середовища, (в першу чергу дій конкурентів), а також можливості та тенденції, які можна використовувати в діяльності;

- сформувати дієву систему мотивації праці до якісного виконання своєї роботи кожним працівником, генерування креативних ідей розвитку підприємства, а також до ввічливого та професійного ставлення до клієнтів;

- удосконалювати організаційну культуру та розвивати креативний менеджмент на підприємстві, тощо.

Висновки. Отже, ТОВ «СПЕЦ ТЕХ ЗАХІД» покращить свої позиції на ринку, завдяки виділеним шляхам удосконалення управління якістю надання транспортних послуг, підвищить конкурентоспроможність, ефективність діяльності, і що саме головне, клієнти зможуть отримати більш якісне надання транспортних послуг.

\section{Список бібліографічного опису}

1. Попова О.Ю., Скибенко Г.Г. Управління якістю як елемент інноваційного розвитку підприємства. Економіка $і$ організація управління, 2014. № 3(19)-4(20). С. 194-198.

2. Кучерук Г.Ю. Економічні методи управління якістю транспортних послуг. Ефективна економіка. 2012. № 7. URL: http://www.economy.nayka.com.ua/?op=1\&z=1257 (дата звернення 20.09.2021). 
Економічні науки: збірник наукових прачь Луиького національного технічного університету. Серія "Регіональна економіка". Випуск 18 (71). Редкол.: відп. ред. д.е.н., професор Л.Л. Ковальська. Луцьк: ІВВ Луиького НТУ, 2021. 278 с.

3. Біліченко В.В., Свершок А.В. Визначення поняття якості пасажирських транспортних послуг та аналіз основних факторів, які на неї впливають. URL: https://ir.lib.vntu.edu.ua/bitstream/handle/123456789/29128/ 9334.pdf?sequence=3\&isAllowed=у (дата звернення 21.09.2021).

4. Офіційний сайт ТОВ «СПЕЦ TEX ЗАХІД» URL: http://spectex.pp.ua/about/

\section{References}

1. Popova O.YU., Skybenko H.H. Upravlinnya yakistyu yak element innovatsiynoho rozvytku pidpryyemstva. Ekonomika i orhanizatsiya upravlinnya, 2014. No 3(19) - 4(20). pp. 194-198 [in Ukrainian].

2. Kucheruk H. YU. Ekonomichni metody upravlinnya yakistyu transportnykh posluh. Efektyvna ekonomika. 2012. No 7. URL: http://www.economy.nayka.com.ua/?op=1\&z=1257. (accessed 20.09.2021) [in Ukrainian].

3. Bilichenko V.V., Svershok A.V. Vyznachennya ponyattya yakosti pasazhyrs'kykh transportnykh posluh ta analiz osnovnykh faktoriv, yaki na neyi vplyvayut'. URL: https://ir.lib.vntu.edu.ua/bitstream/handle/123456789/29128/ 9334.pdf?sequence=3\&isAllowed=y (accessed 21.09.2021) [in Ukrainian].

4. Ofitsiynyy sayt TOV "SPETS TEKH ZAKHID" URL: http://spectex.pp.ua/about/ (accessed 23.09.2021) [in Ukrainian].

УДК 332.02

Вахновська Н.А., к.е.н., доцент

Луцький національний технічний університет

\section{ПОДАТКОВЕ АДМІНІСТРУВАННЯ: РЕГІОНАЛЬНИЙ АСПЕКТ}

У публікації підлягають розгляду питання сутності та мети податкового адміністрування; визначено основні напрямки посилення інституційної спроможності податкових органів в контексті адміністрування податків; обгрунтовано ефективність адміністрування податків у взаємодії із територіальними органами влади.

Ключові слова: адміністрування податків, податкові органи, органи місцевого самоврядування, інституційна спроможність органів влади. 